\title{
AROUND THE THEORY OF ERRORS
}

ŚLĄSKI

PRZEGLĄD

STATYSTYCZNY

Oscar Sheynin

Nr 16(22)

International Statistical Institute,

International Academy of History of Science

e-mail: oscar.sheynin@googlemail.com

ISSN 1644-6739

ORCID: 0000-0002-5039-4314

e-ISSN 2449-9765

DOI: $10.15611 /$ sps.2018.16.05

JEL Classification: C0

\begin{abstract}
The aims of the theory of errors and its relations with statistics are described. The term true value of a constant and the subjective approach in the error theory and statistics are explained and illustrated and a hint at the emergence of a new theory of errors is provided.
\end{abstract}

Keywords: theory of errors and statistics, true value of constant, subjective approach in error theory and statistics.

\section{The theory of errors and its goals}

Here, the author does not describe the new possibility of proving the main conclusion of Gauss' memoir of 1823; see [Sheynin 2014c].

The term Theory of errors (or rather Theorie der Fehler) is due to Lambert [1765, Vorberichte and $\S 321]$. He defined its goals as the discovery of the relations between errors, their consequences (Folgen), the circumstances of measurement, and the trustworthiness of the instruments. Those goals are now different; moreover, Lambert himself had also defined what was later understood as the determinate branch of the error theory which the author briefly mentioned earlier [Sheynin 2014b]. For example, the investigation of the trustworthiness of the instruments is one of its aims.

As understood nowadays, the stochastic branch of the theory of errors has the aim of adjusting direct and indirect observations.

1. Suppose that the observations (measurements) of an unknown constant are

$$
x_{1}, x_{2}, \ldots, x_{n}, x_{1 \leq} x_{2} \leq \ldots \leq x_{n} .
$$

It is required to assign its value optimal in some sense, and to estimate the precision of the result. The observations are supposed to be physically independent and possessing equal weight. Observations of unequal weight can be appropriately weighed. 
PRZEGLACAD STATYSTYCZNY

Nr 16(22)

2. Suppose now that we have equations

$$
a_{i} x+b_{i} y+\ldots+l_{i}=0, i=1,2, \ldots, n .
$$

Here, the free terms are the results of physically independent observations, and the coefficients are provided by the underlying theory. The number of the observations, $n$, is larger than the number $(k)$ of the unknown constants $x, y, \ldots$ Indeed, the solution is otherwise either impossible $(n<k)$ or becomes purely algebraic $(n=k)$, although complicated in the case of large values of $n$ and $k$.

However, if $n>k$ no solution is possible either, and any set of numbers $\hat{x}, \hat{y}, \ldots$ leading to reasonable values of residual free terms (call them $v_{i}$ ) has to be called a solution. Such sets are obtained by imposing some restriction on those residuals, for example, the restriction (condition, principle) of least squares

$$
v_{1}^{2}+v_{2}^{2}+\ldots+v_{n}^{2}=\min .
$$

The method of least squares squarely belongs to the theory of errors.

\section{Adjustment of direct measurements}

During Kepler's lifetime or somewhat earlier the arithmetic mean became the standard estimator of the unknown in the case of direct observations (insert reference to my future note "Kepler as a statistician"). But Al-Biruni (973-1048), for example, when measuring the densities of metals, applied the mode, the midrange and some unspecified value between the extreme observations [Al-Khazini 1983, pp. 60-62].

Ancient astronomers had been choosing the sought estimator almost arbitrarily, as indirectly, but definitely follows from the writings of several historians of astronomy. This attitude was justified by the large errors of ancient observations. To a large extent the same can be stated about statisticians, who, up to the beginning of the $20^{\text {th }}$ century, did not turn to mathematics. And rather late Kaufman [1922, p. 152] argued that curves of distribution, adjustment of series of observations (?), interpolation and correlation are harmful. Earlier, Bortkiewicz [1894-1896, Bd. 10, pp. 353-354] stated that the study of precision was an accessory aim, a luxury, and that the statistical flair was much more important. Perhaps he also had in mind large errors corrupting the data, but his statement was too general. 
Bernstein [1928, p. 231], a most eminent scholar and foreign member of the Paris Academy of Sciences, had an unusual opinion about correlation, or, rather, about its unreasonable applications:

Excluding biological applications, most of its [of the correlation theory] practical usage is based on misunderstanding.

\section{The true value of a constant}

True value of the constant sought is a common expression of the theory of errors, and some statisticians [Chatterjee 2003, p. 264] wrongly consider it outdated, so the author (2007) is refuting this opinion.

Fisher [1922], introduced the first version of mathematical statistics. In particular, without mentioning the theory of errors or real values, he (p. 309) defined the notions of consistent, effective and sufficient estimators of the parameters of distribution functions. Since then, the aim of mathematical statistics has been the estimation of those parameters rather than the determination of their real values.

Now, philosophers long ago indicated that mathematics was becoming ever more abstract but, at the same time, ever more useful. Fisher, therefore, made a significant step in the right direction. But on the very next page he mentioned the true value of an unknown! Many other authors can also be cited here, for example Gauss [1816, $\S \S 3$ and 4], who cannot be separated from statistics, and Hald [2004, p. 105]. Gauss even considered measures of precision which do not exist (at least, in the usual sense) in the real world. Moreover, the theory of errors is applied in experimental science, not only in astronomy and geodesy as in the time of the first meridian arc measurements. And, scientists, to name only metrologists and physicists, cannot, and do not abandon true values.

It was Fourier [1826, pp. 533-534] who offered the first formal definition of true value, and who thus provided this term with a mathematical (instead of its previous philosophical) meaning. The true value, as he stated, is the limit of the arithmetical mean of the measurements of the studied constant as the number of those measurements unboundedly increases.

Obviously, the mean of a sufficiently large number of measurements. Several authors (Lambert, Laplace) stated the same or almost the same even earlier, and many authors later repeated the Fourier definition without referring to anyone. Note also that it, the definition, heuristically resembles the definition of probability introduced by Mises. 
ŚLĄSKI

PRZEGLẠD STATYSTYCZNY

Nr 16(22)

Fourier also remarked that the observations ought to be carried out under unchanged conditions (circumstances) which is indeed obligatory in metrology, but simply wrong for geodesy: lateral refraction which corrupts geodetic measurements changes during the day, and a representative sample of measurements ought to reflect those changes. But even in metrology it is natural to compare the results of measurements made in different laboratories.

Unavoidably, the Fourier definition means that the residual systematic error of measurements is included in the true value. Here, indeed, is the testimony of a metrologist [Eisenhart 1963, p. 31]:

The mass of a mass standard is [...] specified [...] to be the mass of the metallic substance of the standard plus the mass of the average value of air adsorbed upon its surface under standard conditions.

\section{The subjective approach}

This in fact is necessary. In the theory of errors the weighing of observations and the rejection of outliers [Sheynin 2014a, p. 24] are to a large extent carried out subjectively. In statistics, many decisions have to be made in the same way (the simplest example: the grouping of observations). Then, the same is true concerning the planning of sample surveys, the work of experts etc.

\section{The theory of errors is not known sufficiently well}

Donahue, the meritorious translator and commentator of Kepler's [1609] fundamental contribution, did not say a word about Kepler's adjustment of observations (see Kepler as a statistician). Modern astronomers obviously lost interest in that subject. The same is, and even was true about mathematicians. Chebyshev [1879-1880, pp. 250-252] described the method of least squares according to Laplace, criticized Gauss [1809] and did not mention Gauss [1823]. Fisher [1925, p. 260] thought that the method of least squares is a particular application of the principle of maximum likelihood. This is only true in the case of the normal distribution but does not concern Gauss [1823]. And Poincaré [1896, § 127] did not recognize that fundamental contribution but he obviously had not studied Gauss. Statisticians (Karl Pearson and Yule) discovered (likely, rather too late) that the results of Gauss could apply for developing the theory of correlation; in more detail, see [Sheynin 2014a, p. 26]. Here is a quote from the distinguished Russian mathematician Tsinger [1862, p. 1]: 
In Laplace's work we find a rigorous [?] and impartial study of this problem. His analysis shows that the results of the method $[\ldots]{ }_{\mathrm{Nr} \text { 16(22) }}$ only enjoy a more or less substantial probability when the number of observations is large whereas Gauss attempted to attach absolute meaning to this method, using extraneous considerations

and applying it to a small number of observations when

we cannot at all reckon upon the mutual cancellation of errors $[\ldots]$ and $[\ldots]$ any combination of observations can $[\ldots]$ lead as much to the increase of errors as to their decrease.

The author was ignorant of the second Gaussian justification of the method of least squares; of Gauss' qualification remark [1823, § 6] about the arbitrariness of his method; or of Gauss' correct decision to restrict his attention to the case of a small number of observations. Finally, both the history of the sciences of observation and of mathematical statistics proved that Tsinger's last lines contradicted reality and theory, respectively.

A very special point is provided by the non-existing Gauss - Markov theorem which, nevertheless, is still mentioned [Dodge 2003, p. 161]. Actually, it only concerns Gauss [1823]. Here is the story of that mysterious theorem.

Neyman [1934, p. 595] mistakenly attributed to Markov the second Gaussian justification of least squares of 1823. David and Neyman [1938] repeated that mistake, but then Neyman [1938, p. 228] admitted it. H. David (after 2001) noted, in an unpublished manuscript, that it was Lehmann [1951] who invented that unfortunate name. Neyman's wrong initiative seems strange since he [1934, p. 593] contradicted himself:

The importance of the work of Markov concerning the best linear estimates consists, I think, chiefly in a clear statement of the problem.

\section{A new theory of errors}

A new theory seems to be emerging. The author can only refer to June [2015] who mentions immense numbers of observation in several branches of natural sciences and the ensuing necessity of a new theory. He was not really versed in the history of the theory of errors and, as it seems, too easily all but rejects it, but in any case new thoughts are probably needed. Regrettably, he had not concisely described the essence of this new theory. 


\section{ŚLĄSKI \\ PRZEGLĄD STATYSTYCZNY \\ References \\ Nr 16(22)}

Al-Khazini, 1983, Kniga Vesov Mudrosti, Nauchnoe Nasledstvo, vol. 6, pp. 15-140.

Bernstein S.N., 1928, The present state of the theory of probability and its applications, Sobranie Sochineniy, vol. 4. Moscow, 1964, pp. 2172-2, S, G, 7.

Bortkiewicz L. von, 1894-1896, Kritische Betrachtungen zur theoretischen Statistik, Jahrbücher f. Nationalökonomie u. Statistik, 3. Folge, Bd. 8, pp. 641-680: Bd. 10, pp. 321-360; Bd. 11, pp. 701-705.

Chatterjee S.K., 2003, Statistical Thought: a Perspective and History, Oxford.

Chebyshev P.L., 1879-1880, Teoria Veroiatostei, Moscow-Leningrad, www.sheynin.de, Document 3.

David F.N., Neyman J., 1938, Extension of the Markov theorem on least squares, Stat. Res. Mem., vol. 2, pp. 105-117.

Dodge Y., 2003, The Oxford Dictionary of Statistical Terms, Oxford.

Eisenhart C., 1963, Realistic Evaluation of the Precision and Accuracy of Instrument Calibration Systems, [in:] Ku H.H. (ed.), Precision Measurement and Calibration, Nat. Bureau Standards, Sp. Publ. 300, vol. 1, pp. 21-47.

Fisher R.A., 1922, On the mathematical foundations of theoretical statistics, Phil. Trans. Roy. Soc., vol. A 222, pp. 309-368.

Fisher R.A., 1925, Statistical Methods for Research Workers, edition of 1973 with separate paging in author's Stat. Methods, Experimental Design and Scient. Inference, Oxford.

Fourier B.J, 1826, Sur les résultats moyens, Oeuvr., t. 2. Paris, 1890, pp. 525-545.

Gauss C.F., 1809, Theorie der Bewegung, Book 2, section 3. In Gauss (1887, pp. 92-117).

Gauss C.F., 1816, Bestimmung der Genauigkeit der Beobachtungen, Ibidem, pp. 129-138.

Gauss C.F., 1823, Theory of the combination of observations least subject to error, Philadelphia, 1995, translator G.W. Stewart with Afterword.

Gauss C.F., 1887, Abhandlungen zur Methode der kleinsten Quadrate, Hrsg. A. Börsch, P. Simon. Vladuz, 1998.

Hald A., 2004, History of Parametric Statistical Inference from Bernoulli to Fisher, 1713 to 1935, Copenhagen.

June I.V., 2015, Neklassicheskaya Teoria Pogreshnostei Izmereniy, Rivne (Rovno), 2014.

Kaufman A.A., 1922, Teoria i Metody Statistiki, Moscow, fourth edition, German edition: Theorie und Methoden der Statistik, Tübingen, 1913.

Kepler J., 1609, New Astronomy, translator W. Donahue, Cambridge 1992.

Lambert J.H., 1765, Anmerkungen und Zusätze zur praktischen Geometrie, in author's Beiträge zum Gebrauche der Mathematik und deren Anwendungen, Tl. 1, Berlin, pp. $1-313$.

Lehman E.L., 1951, A general concept of unbiasedness, Annals Math. Stat., vol. 22, pp. 587-592.

Neyman J., 1934, On two different aspects of the representative method, J. Roy. Stat. Soc., vol. 97, pp. 558-625, in author's book (1967), Selection of Early Statistical Papers. Berkeley, pp. 98-141.

Neyman J., 1938, Lectures and Conferences on Math. Statistics and Probability, Washington, 1952.

Poincaré H., 1896, Calcul des Probabilités, Paris.

Sheynin O., 2007, The true value of a measured constant and the theory of errors, Historia Scientiarum, vol. 17, pp. 38-48. 
Sheynin O., 2014a, C.F. Gauss and the method of least squares, Śląski Przegląd Statystyczny, Silesian Stat. Rev., no. 12 (18), pp. 9-36.

Sheynin O., 2014b, Theory of errors. Some thoughts about Gauss, Śląski Przegląd Sta- Nr 16(22) tystyczny, Silesian Stat. Rev., no. 12(18), pp. 53-54.

Sheynin O., 2014c, Elementary exposition of Gauss' final justification of least squares, Śląski Przegląd Statystyczny, Silesian Stat. Rev., no. 12(18), pp. 39-47.

Tsinger V.Ya., 1862, Sposob Naimen'shikh Kvadratov, Moscow.

\section{O TEORII BLĘDÓW}

Streszczenie: Głównym celem artykułu jest opisanie teorii błędów i jej związku ze statystyką. Wyjaśniono i zilustrowano pojęcie prawdziwej wartości stałej oraz subiektywne podejście $\mathrm{w}$ teorii błędów i statystyce wraz ze wskazaniem potrzeby pojawienia się nowej teorii błędów.

Słowa kluczowe: teoria błędów, statystyka, prawdziwa wartość stała, podejście subiektywne. 